\title{
A multifarious understanding of eschatology in Ephesians: \\ A possible solution to a vexing issue
}

\author{
HR Lemmer \\ University of South Africa
}

\begin{abstract}
A multifarious understanding of eschatology in Ephesians: A possible solution to a vexing issue
\end{abstract}

Although an almost forgotten debate, the issue of eschatology in Ephesians remains unresolved and possibly insoluble. However, presuppositions inevitably determine the final outcome of investigations. This latter datum is characterized, indicating the outcome of the investigations of both those who would endorse and those who would deny the premises of the Early Catholicism Hypothesis. By postulating that differences from so-called authentic Pauline letters in Ephesians are merely as a result of addressing a different contingent situation, as well as by accepting that the composite eschatological profile in Ephesians is merely an adaptation of Pauline eschatology to that specific contingent situation, it is argued that it is possible to retain futuristic eschatological dimensions in Ephesians.

\section{INTRODUCTION}

The outcome of all understanding of the Bible is contingent upon hermeneutics which, based on presuppositions, is rooted in contemporary philosophy, resultant from a current world view. This understanding is also shaped by present-day thought constructs. This obvious datum is no less true of the understanding and

\footnotetext{
- The following material is an adaptation from a doctoral thesis: Lemmer, HR 1988. Pneumatology and eschatology in Ephesians - the role of the eschatological Spirit in the church. An ad hoc bursary by the HSRC is hereby acknowledged.
} 
interpretation of the moot point of Ephesian eschatology. It is also true of the postulated answer to the problem by the present author.

There has been no lack of interest in this topic, and in fact, several major investigations have been carried out in this regard ( $\mathrm{cf} 2$ below). It is especially the Early Catholicism Hypothesis (henceforth, $\mathrm{ECH}$ ) that has played a major role in the shaping of the outcome of investigations on Ephesian eschatology. For a formal but brief discussion of the basic roots and tenets of the ECH, see Lemmer (1988: 53-81). It can be clearly detected that much if not all research on Ephesians, especially during the last twenty five years, has been affected either directly or indirectly by the ECH. It is particularly in Roman Catholic circles that much substantial research has been done and it is exactly here where this hypothesis has acted as a determinant. However, one of the major protagonists of this hypothesis is the Lutheran Protestant, Käsemann (cf Lemmer 1988: 63-81, for a précis of his contribution to this hypothesis). Roman Catholics and Protestants have different interests at heart when accepting the validity of this hypothesis (cf Lemmer 1988: 56-63).

Three tenets of the ECH are of special importance here: (a) the development of ecclesiology to where the church became a Heilsanstalt; (b) the consequent supplanting of the imminent return (or indeed, any return) of Christ; and (c), both preceding as well as succeeding (a) and (b), the fact that any resemblance to Pauline thinking emanates from a wholesale borrowing of traditional material, rather than being indicative of Pauline authorship itself (cf Lemmer 1988: 69-76).

One of the main objectives of this article, is to characterize the outcome of the major research done on the eschatology in Ephesians thus far. This will be arranged in three categories: Firstly, investigations that would concur with the above tenets of the ECH; secondly, investigations that would deny the above tenets; and thirdly, the outcome of the present author's investigation (Lemmer 1988). This will be followed by a brief evaluation of some preceding studies in the light of the latter. *

\section{CHARACTERIZATION OF RESEARCH DONE ON EPHESIAN ESCHA- TOLOGY}

The major existing research may basically be divided between those who would concur on some tenet (or the entire) of the $\mathrm{ECH}$, and those who deny the validity of such a hypothesis. The bases of these hermeneutical variances are admittedly more complex than this classification. It is also true that these points of departure are so

- Generally, the approach adopted in Sections 2 and 3 below, is that of a survey and synthesis, rather than an evaluation of the merits and demerits of arguments. 
radically different, that 'ne'er the twain shall meet'. Rather than supplying a précis of each investigation, issues which commonly characterize the two major approaches will be arranged as rubrics. *

\subsection{Investigations that find it impossible to accept traditional futuristic eschatology} Major investigations here are those of Mussner (1955 - this work, Christus das All und die Kirche. Studien zur Theologie des Epheserbriefes, was not available; \& 1963); Steinmetz (1969a; 1969b); Lindemann (1975); and more recently Lona (1984). The understanding of the ensuing aspects described as follows, characterizes this approach.

\subsubsection{History and eschatology}

There is an innate conviction here that the Ephesian author did not merely write from some kind of salvation historical perspective, but characterized history afresh, either as completely sacred, or as innately evil and therefore the author avoided any temporal categories; dealing merely with the 'eternal now'. This aspect can be diversified into the following characterization; some of them posing the obvious inverse of the other.

2.1.1.1 Either history is viewed as entirely sacred or as entirely evil; or as nonexistent

The first option is followed by Mussner (1963) who postulates that Ephesians as 'history-theology' (Mussner, Geschichtstheologie) amounts to the fact that the author thereof unfolds certain primordial confessions (Mussner 1963: 63) which unveil the mystery of the ages, according to which Christ is the hidden Lord of the world, who now rules. Furthermore, in Ephesians, Israel is replaced by the church as the 'center of time' (Mussner 1963: 59-60) and any salvific part for Israel is suspended. The new epoch is totally different (Mussner 1963: 60) and there is no longer any dualism between Israel and the Gentiles, since these two entities have been synthesized in the church; moreover, 'Der eschatologische Impetus Israels ist auf die Kirche übergegangen, ...' The church finds itself in an eschatological battle situation which is also a cosmological situation (Mussner 1963: 60). The following observation of Von Balthasar depicts to Mussner the inextricable interweaving of

- This summary is done on an ad hoc basis to fit into the limitations of this article, and no claim is made of completeness. Furthermore, it should be noted that the present author is well aware that the four respective authors' viewpoints are not monochronic; i e they may respectively not imply the same meaning, when referring to the same concept. 
history and theology as developed in Ephesians:

... die 'Differenz zwischen einer besonderen.... Heilsgeschichte und einer allgemeiner profanen Geschichte' aufgehoben ist: 'seit Christus ist alle Geschichte grundlegend 'sakral', aber sie ist es nicht zuletzt durch die bezeugende Gegenwart der Kirche Christi innerhalb der einen, totalen Weltgeschichte'.... (Mussner 1963: 62; my italics).

Lindemann (1975) also deals with the relation between history and eschatology in Ephesians, hence the subtitle of his thesis: Geschichtsverständnis und Eschatologie im Epheserbrief. Among others, he addresses the question whether 'time' and 'history' have lost their relevance or whether it is just for the Christian that there is no more time (Lindemann 1975: 237). According to Lindemann, it may be assumed that should the thesis of Kâsemann be acceptable, the Ephesian author understood history as a demonic creation (dämonisierte Schöpfung - Lindemann 1975: 237) and expected victory over the demonic forces and the restoration of creation.

However, since the redactor of Ephesians treats the world historically, it merely constitutes the background against which salvation is revealed and the redactor does not have its nature in mind. He only focuses on the existence (Existenz) of the Christian, which concurs with the now of the church. Nevertheless, not even the church exists within history, since the present existence of the church is in heaven (Lindemann 1975: 237-8).

\subsubsection{Suspension of temporal categories altogether}

Ineluctably linked to the former aspect is the issue of the relationship between temporal and spatial categories. Lindemann (1975: 49-66) addresses the subsidiary problem of the relation between time and space in Ephesians and postulates (Lindemann 1975: 49) that in Ephesians these dimensions are closely related. It differs from the Pauline letters, because traditional time pronouncements are now changed into spatial pronouncements. The usual futuristic resurrection (temporal category) of the Christian, is portrayed as having already taken place, since the Christian already shares heaven with the Christ (spatial category). Instead of the usual tripartite universe (heaven, earth and under the earth), we simply have that which is 'from above' and that which is 'from below'. However, this two-part universe does not present a dualism (Lindemann 1975: 50):

... im Gegenteil: das Weltbild des Briefes ist ausgesprochen antidualistisch, wie Eph 3: 15; 4: 6 zeigen.... Auch das Böse ist nicht 
ein widergöttliches Prinzip, erst recht nicht ein 'zweiter Gott', sondern es ist 'unter' worfen - Gott steht nicht neben, sondern über ihm.

Heaven and earth are, in fact, areas distinguished by different 'lords' or 'sovereigns'. However, both are subjugated to God. This indeed explains the possibility of good and evil forces both sharing the heavenlies.

In Lindemann's (1975: 67-192) discussion of the conception of time in Ephesians, more specifically the relation between 'past' and 'present', he found that the 'redactor' developed the idea of 'the suspension of time' and did not know about any categories of history (Lindemann 1975: 193). Lindemann (1975: 339) affirms that temporal categories are replaced by spatial categories basing his argument on the fact that Ephesians 2: 5-10 and 6: 10-18 indicate that eschatology had been changed into 'heavenly ecclesiology'. This implies that Ephesian eschatology is präsentische Eschatologie (Lindemann 1975: 239), which is changed into a doctrine or teaching of the order of the heavenly region.

\subsubsection{No futuristic but only realized eschatology}

An inevitable corollary of the former understanding of history is the denial of any possible existence of futuristic dimensions of eschatology in Ephesians since all eschatology has been realized: 'Das Eschaton ist bereits Vergangenheit bzw. Gegenwart, die Anakephalaiosis des Kosmos ist Gegenwärtige Realität (1: 10).' (Lindemann 1975: 237).

\subsubsection{Reinterpretation of any temporal notions in Ephesians}

It has to follow from the former aspect that all intimations of future or temporal notions, necessitate a different understanding. Thus Lindemann (1975: 237) addresses the question whether all temporally (with a view to the future) designated eschatology is also eliminated, since a number of traditional eschatological pronouncements occur in Ephesians. After investigating these, he (1975: 237) concludes that in Ephesians a precise distinction between the 'understanding of history' and 'eschatology' is not possible:

... vor allem die Abschnitte 1: 20ff und 2: 5ff machen deutlich, dass sich für den Verfasser des Briefes Vergangenheit, Gegenwart und Zukunft zeitlich zu einer Einheit verbinden. Insbesondere gilt, dass das, was der traditionelle christliche Glaube von der Zukunft erwartet und erhofft, nach der Theologie des Epheserbriefes bereits geschehen ist. 
Lindemann interprets the ideas of 'development' and 'growth' in Ephesians as a development within an already completed building, '... das 'Wachsen' des Baus ist gerade deshalb möglich, weil dieser Bau bereits vollendet ist!' (Lindemann 1975: 239). This is, however, a history within space - a horizontal development within a vertical. On this basis he rejects any hint that the growth and fulfillment concepts are an equivalent for a parousia expectation, because these 'growth notions' should be seen from the perspective of the pronouncements that indicate everything as already completed (Lindemann 1957: 239).

Although Lona (1984) postulates a different Sitz im Leben, nevertheless, he similarly has to re-explain the existing eschatological pronouncements (Lona 1984: 418-428). He analyzes the traditional futuristic texts in Ephesians (1: 13f; 1: 2 lf; 4: 30; 6: 13) and allows for two possibilities: Either these texts should be viewed merely as 'rests' of traditional eschatology without any weight for a particularly futuristic eschatology for Ephesians, or these elements bring a new perspective into focus that serve as a correction in the strong praesentic view of salvation in the church in Ephesians. He then concludes that by adopting the theme of the Spirit as appaßwu, the redactor remained in line with general Pauline eschatology (Lona 1984: 427). Ephesians 6: 13 and 1: 21, in spite of their links with classical Jewish eschatology, here remain aloof from any binding to temporal presentations (Lona 1984: 427). Ephesians 1: 13 and 4:30 indicate that there is no contradiction between the present and the future salvation (Lona 1984: 427). However, none of the four references fulfill the function of presenting a concrete eschatology, 'Der Tag der Erlösung (4: 30) und der böse Tag (6: 13) werden zwar erwähnt, aber sie gehören nicht in eine 'Konkrete' Eschatologie' (Lona 1984: 428).

\subsubsection{Denial of Pauline authorship}

It is commonly accepted by the former scholars that Ephesians was at best composed by a redactor of some sort. See for example the conclusions of Lona (1984: 30-34) in this regard. This concurs with the posit that Ephesians reflects a later stage in church history.

\subsubsection{Gnostic rather than Jewish or Qumranic Traditionsgeschichtliche roots}

Lindemann inquires into the history of religions for possible answers for the development of temporal into spatial categories (cf Lindemann 1985: 121-123). He (1975: 244) rejects Qumranic influence as being determinative for the understanding of eschatology in Ephesians: 
... Qumran-'Parallelen' etwa zu 2: 5 ff lassen sich nur metaphorisch, nicht aber konkret räumlich verstehen, und vor allem enthalten sie durchweg den eschatologischen Vorbehalt, ... Die Theologie des Ephesersbriefes basiert auf der Vorstellung vom Ende der Zeit, in Qumran wird dieses Ende gerade noch erwartet.

Lindemann deems Gnostic influences more possible and sees a reciprocal influence between Gnosticism and Christianity whilst the author of Ephesians utilizes both Pauline and Gnostic conceptions in certain parts of Ephesians 2. He (1975: 247) finds this especially in the Gnostic portrayal of the church. Any temporal eschatological designations in the paraenetic sector of Ephesians are viewed as traditional material without any real temporal designations. Lindemann allows for more Gnostic (by metonomy, Platonic) influences. He concurs with the idea of Käsemann that there is a transition here in the eschatology of the early church from an overtly early parousia expectation, in which the conventional temporal and spatial dualism of apocalyptic are essentially normative for authentic Pauline Christianity, to an adapted eschatology.

\subsubsection{An exalted ecclesiology}

It was already seen in Mussner's reference to history and eschatology (2.1.1.1 above) that the church assumes an exalted position. Similarly, and yet more pronounced in the opinion of Lindemann (1975: 238), the church is to be understood as a timeless entity. The redactor wants to portray the church as a timeless eternal structure, as that which is 'now', always 'was', and consequently 'will be' in eternity. As far as the Ephesian author is concerned the earth is simply 'not-church' (Nicht-Kirche). There is no world of evil and the world of God, heaven is the realm of the church and the Christian, that which is above where the ages are already being revealed. This idea of timelessness is innately and necessarily an ingredient of the theological-systematic position of the letter:

... das jetzige Sein Der Kirche in den Himmeln, ihre 'Gegenwart' also, ist ja zugleich ihr endgültiges Sein - 'Zukunft', die doch nur als Veranderung der Gegenwart verstanden sein könnte, kann es aus diesem Grunde nicht geben (Lindemann 1975: 238).

However, the distinction between the church and the world lies therein that the end of time and the end of the world are simply fulfillments of the will of God, while to the Christian they present the salvific acts of God which are expressed in the 
participation of the Christian in the fate of Jesus (Lindemann 1975: 238-9).

Although in a different sense, Lona (1984: 81) also maintains that the church fulfills a cohering force, in that eschatology should be read from the viewpoint of ecclesiology. In his view, eschatology in this letter is a theological Gesamtkonzeption which can be brought under the denominator of ecclesiology (Lona 1984: 81), so that one can characterize eschatology in Ephesians as ekklesiologische Eschatologie (Lona 1984: 442). The general presentation of the redactor shows that he does not have eschatological issues in a narrow sense in mind. However, this is more clearly detected when he deals with the understanding of time in Ephesians. After an investigation of Ephesians 2: 1-5; 2:11-3 and 5: 8, he concludes that time is cast within a negative perspective. The church replaces and supersedes time as 'Heilsinstanz' (Lona 1984: 269). This, however, is not based on any heilgeschichtliche developments. This accentuation of the church is also clear from the next main inquiry made by Lona into the relationship between eschatology in Ephesians and the contingent situation of the readers (Lona 1984: 428-48): Firstly, he postulates a possible general and specific Sitz im Leben (Lona 1984: 430-40). To this situation, the redactor answered in a letter with an appropriate eschatology. The essential answer of the redactor (Lona 1984: 442-8) however, was not eschatological but ecclesiological. 'Das verhältnis dieser Aspekte der Eschatologie zur Gemeindesituation ist nicht unmittelbar gegeben, sondern wird durch die Eschatologische Qualifisierung der Ekklesiologie vermittelt' (Lona 1984: 445).

The present writer differs from Lona's view (see 4.1.2) that Ephesian eschatology is essentially ecclesiological and that it is merely incidental. This view is evidenced by the following statement about the occurrence of eschatology in the paraenetic section of the letter: 'Hier konnte auch die Eschatologie des Briefes nicht helfen. Sie hatte ihre Funktion im Zusammenhang mit der Ekklesiologie auf einer grundsätzlichen Ebene erfüllt' (Lona 1984: 448).

$2.2^{\circ}$ Researchers that find it unnecessary to deny futuristic eschatology from Ephesians

In a merely exemplary fashion, reference is made here to Caragounis (1977), Barth (1974 \& 1984) and Lincoln (1981).

Except for Lincoln, who deals with Pauline eschatology as such, although mainly from one perspective, none of these works can be classified as major works on the topic. Nevertheless, they investigate cognate aspects and therefore sufficiently characterize the outcome of investigations on eschatology. 


\subsubsection{No apriori rejection of futuristic eschatology}

Characteristic of this approach is the supposition that futuristic eschatology is a sine qua non, along with the concurrent existence of realized eschatology.

Barth (1974) consistently concludes (sometimes after lengthy discussions) in all the relevant Ephesian passages, that the Ephesian author unequivocally maintains a futuristic perspective, however, portrayed in different imagery (see for example his comments on 4: 13). He (1974: 440-1) even espouses the view that the growth and fulfillment concepts indicate a parousia expectation.

Caragounis (1977: 136-9) is of the opinion that regarding the $\dot{\epsilon} v$ dimension in

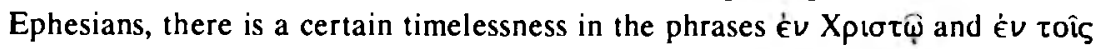
Éroupaviors. However, the fact that these phrases indicate another dimension does not simply mean a dualism, although that may be inferred. The concept of

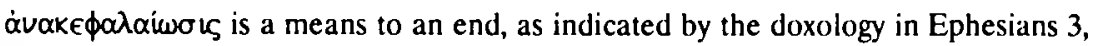
which supreme end is the worship of God by the church, who experienced the

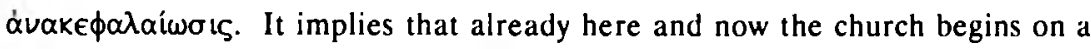
course of action and a mode of being - praising Him - which belongs properly to an 'eschatological time', that is, to the avakeфaraiwo ts and 'beyond it' (Caragounis

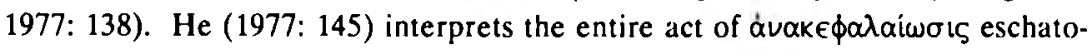
logically, both present and future:

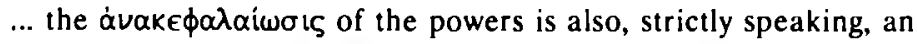
eschatological concept, which shall transpire when the Christian shall

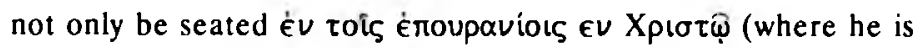
already), but shall cease his fight against the powers and be effectively joined to His Head as a member of the body.

There is then, however, a clear openness in Caragounis' findings as regards the probability of futuristic eschatological dimensions in Ephesians with a clear recognition of the present eschatological participation by the Christian (the church).

Similarly the entire matter of the Gentiles being incorporated into the salvific economy of God is seen as indicative of an eschatological act by the usage of mysterion (Caragounis 1977: 141-2): 'It was noted in another connection that the mysterion of 1: $9 \mathrm{f}$ is the all-comprehending eschatological personage of God as made known to the author ...' (Caragounis 1977: 141). And in the proclamation of

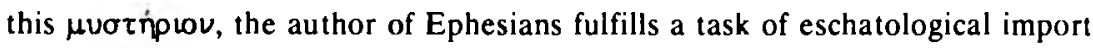
(Caragounis 1977: 143).

Lincoln, who devotes a fairly lengthy treatment of the heavenly perspective in the eschatology of Ephesians (Lincoln 1981: 133-166), admits in his discussion of 
Ephesians, heaven and realized eschatology (1981: 166-8) to the predominance of realized eschatology in Ephesians, but denies that this '... necessitates a rejection of futuristic eschatology.' There is still a clear indication of the role of the future in Ephesians. According to Lincoln (1981: 167), this is reflected in Eph 1: 14;2: 7; 4: $30 ; 5: 5 ; 6: 8 ; 13$ and $1: 21$ and elsewhere. The relationship of the double eschatological perspective is seen in the light of '... the Pauline indicative and imperative with its "Become what you are"' (Lincoln 1981: 167). This, however, is a twofold focus, and neither aspect should be played down. An interesting observation is that the realized aspects play a more prominent role in the more liturgically cast chapters of Ephesians (1-3), and vice versa (Lincoln 1981: 167).

\subsubsection{Jewish-Qumranic influence is more probable than that from Gnostic or} mystery religions

Caragounis is certain that correspondence in usage of $\mu$ utriplov, in both Ephesians and Qumranic writings, makes the latter a possible source for the Ephesian occurrence. Nevertheless, he (1977: 134) is careful to note: '... the connection between Qumran and Eph will have to be demonstrated, for it cannot be assumed as

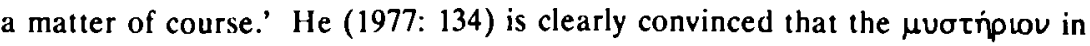
Ephesians '... belongs to the Jewish (sic) tradition of designating God's riches, truths and plans as a 17 or $\mu$ urinplov.' Caragounis (1977: 120-1) rejects, on the basis of uncertain origins, Gnosticism as well as the mystery religions, as a possible background. His claims (which are as cogent as those who accept Gnostic and hence Greek influence) to a more Jewish background, leads him to pose indirectly a more Jewish apocalyptic view of eschatology in Ephesians (Caragounis 1977: 117$135)$.

Lincoln (1981: 169-184) finds clear links, concurrences and convergence with Jewish modes of apocalyptic thought, both temporal as well as spatial. The reasoning of Lincoln (1981: 170-4) in a discussion of heaven and the two ages in which Ephesian passages are frequently referred to, appears to be convincing since he has acquainted himself thoroughly with the apocalyptic material itself (see also his discussion on Paul, heaven and apocalyptic (Lincoln 1981: 174-180). However, in spite of the strong Jewish Vorlage and tradition, it allows for Hellenistic influences as well. Lincoln (1981: 178) relies especially on the findings of Hengel, who dispelled '... the misconception that spatial terminology must necessarily be Hellenistic and to show the combination of spatial and temporal categories in apocalyptic.' And positing '... a general syncretistic context means that again the Hellenistic-Jewish thought world is likely to provide some of the closest parallels for many concepts in Ephesians ...' (Lincoln 1981: 139). 
Generally, the approach of Lincoln does more justice to the probability of both Jewish and Hellenistic backgrounds of Ephesians, and it is especially this inclusive approach which is appealing and persuasive.

\subsubsection{This view is partial to the probability of Pauline authorship}

Denying traditional eschatological categories in Ephesians is an inevitable cause or corollary of accepting non-Pauline authorship. The inverse of this is also true, see, for example, Lincoln (1981: 135) who indicates his preference for Pauline authorship and consequently maintains a more traditional profile of Pauline eschatology in Ephesians.

2.2.4 Rather than considering Ephesians to be an aberration of accepted 'Paulinism', this view postulates a different contingent historical situation

It seems that rather than any radical development or difference in authorship, it is the contingent historical situation (whatever this situation was) that is the determinant in the different focus of eschatology. This is clearly argued by Lincoln (1981: $177 ; 182$ ) in his posits for possible divergence in eschatological emphases, namely its directness to the specific contingent situation. This approach is similar to that followed by the present author (cf 3. below). In this approach Lincoln (1981: 181-4) concurs with Beker's proposition for contingency, postulating this in his discussion of a possible development in Paul's eschatology: 'We are on safer hermeneutical ground in taking the course followed in this study, of examining the form and function of Paul's eschatological language in its various settings' (Lincoln 1981: 182; italics HRL).

2.2.5 The seemingly different traditions contained in Ephesians are quite reconcilable with Pauline thinking

One may here merely refer to the monumental work done by Van Roon (1974) as well as the more recent and clear article by Barth (1984), to see that Ephesian thought constructs can comfortably be reconciled to those writings accepted as genuinely Pauline.

\section{MULTIFARIOUS ESCHATOLOGICAL PERSPECTIVES IN EPHESIANS}

\subsection{Basic premise and methodology}

It was here endeavored to allow the text to dictate in its widest circumference the parameters of a possible contingent situation, rather than opting for a reductionist 
or either-or approach which just accepts the one or other perspective on eschatology (Lemmer 1988: 27-31; 116-133). Furthermore, to fit into this postulated Sitz im Leben and raison d'être it is presupposed that the eschatology contained in the letter is rather an adaptation to the posited contingent situation than an aberration of Pauline eschatology. The following two variables (the hermeneutical premise, as well as the postulation of the relatedness of pneumatology and eschatology) acted as determinants in the outcome of this investigation.

\subsubsection{A basic hermeneutical and methodological premise}

The data portrayed on the profile of Ephesian eschatology in 3.2 below, was synthesized in the following manner: On the basis of a similar premise as that put forth by Beker (1980; cf the discussion of Lemmer 1988: 23-24), albeit with the acceptance of Pauline authorship of Ephesians, it was postulated that Paul adapts his traditional eschatology to address the contingent situation of the letter. By means of a synchronic analysis (Lemmer 1988: 116-133), such a hypothetical contingent situation was extrapolated from the letter. Thereafter an analysis of smaller relevant units in the discourse was carried out.

3.1.2 Pneumatology and ecclesiology as coordinates for the understanding of eschatology in Ephesians

This datum of coordinates clearly emerged in the research under discussion (cf Lemmer 1988: $487-501$ and especially $489-493$ for a reflection of, The relatedness of the triad: Pneumatology, eschatology and ecclesiology). Initially the notion that the understanding of eschatology in Ephesians may be facilitated from the perspectives of the Spirit and the church, was partly a supposition but was later confirmed as a definite result of the investigation: Namely, that here is an innate relatedness between eschatology and pneumatology (and vice versa) which implies that both a study of the relatedness as well as the investigation of pneumatology as such will furtber elucidate the understanding of the eschatology of Ephesians.

The latter is confirmed by the opinion of Adai (1985: 61-84, cf also 274) who however, merely posits that the pneumatology of Ephesians facilitates understanding of the moot aspect of eschatology:

Obwohl in christologischer Hinsicht ... das Heil schon realisiert ist, ist in pneumatologischer Hinsicht das endgültige Heil noch nicht realisiert. Dieser Befund ist der Schlüssel zum Verständnis der Eschatologie des Eph. 
A complete understanding of Ephesian eschatology can therefore not be arrived at without analyzing it in its interaction with pneumatology and ecclesiology. Nevertheless, the following contours may be drawn from the emerging perspectives. The main reason for this specific characterization of eschatology is that from this a different perspective can be cast upon the Spirit and the ecclesia when they are viewed together.

\subsection{Characterization of eschatology in Ephesians}

The following discussion merely reflects the salient perspectives; for the actual substantiation thereof, see Lemmer (1988).

\subsubsection{Spatial dimensions in Ephesian eschatology}

From the beginning of the Ephesian discourse, a clear spatial dimension is portrayed. The entire salvific design started from heaven and leads back to heaven. Indeed, eschatology is already contained in proctology, however, here only true in a spatial sense.

It is especially the aspects of proleptic and praesentic eschatology that are denoted by the spatial dimensions of heaven-earth, above-below. The latter datum is especially validated by the way in which the Spirit links heaven to earth and vice versa. This spatial interaction by the Spirit, however, does not negate the temporal, since these are only occasional impingements.

\subsubsection{Temporal dimensions in Ephesian eschatology}

The tension that exists in Ephesian eschatological thinking is not between the spatial and temporal, but occurs strictly in the temporal dimension in the following way: That which is experienced in the spatial realization of the Spirit from heaven here and now, must inevitably incite the believers to anticipate yet a greater realization, when the present and the anticipated future will concur (1: 13-2: 10). This anticipation (reflected, for example, in the concept of $\dot{\alpha} p \alpha \alpha \beta \omega v$ ) indicates that much is still extant, such as the full entrance and access into the presence of the Father. In the temporal dimension there is a clear past and future perspective. The very fact of the extant fulfillment of the inheritance, as well as the future day on which this will take place substantiate the futuristic perspective. This is further underscored by the fact that a terminus ad quem is envisaged for the completion of the ecclesia, intensively but also extensively.

The futuristic perspective neither underscores nor negates any notion of an imminent return; this idea is simply not patently referred to in Ephesians. The temporal dimension is not only underscored by the final day as a day of deliverance, 
but also inasmuch as that day may be the harbinger of judgment.

\subsubsection{Correlation between spatial and temporal eschatology}

The temporal dimensions are clearly juxtaposed to the spatial in Ephesians (1: 3-14; 2: 6-7). However, the author does not intimate any tension between these dimensions. In fact, at times they are made to coincide with one another. This happens when the spatial impinges upon the temporal, for example, in the experience of the believers during worship.

In God's designs the spatial and temporal dimensions of eschatology fecundate and interact with one another to bring about His ultimate intended completeness of measure. The one aspect is never portrayed as suspending the other. Nevertheless, in the church's experience of the presence of the Spirit, the Spirit at given moments seemingly suspends both space and time, although He does not obliterate either. Also in the life of the church these two dimensions exist alongside each other, whilst the datum of the proleptic exaltation (spatial aspect), with, and in the Christ, remains a constant. There are those impingements by the Spirit that makes the church realize that the final fulfillment is still extant. One such occasion where the spatial and temporal coincide, may be the Lord's supper and during the concomitant worship (Lemmer 1988: 403-453).

\subsubsection{Fourfold character of Ephesian eschatology}

The following composite character of eschatology in Ephesians follows as a result of further conclusions drawn from the former three perspectives.

\subsubsection{Proleptic eschatology}

The author of Ephesians interprets the entire eschatological process from the viewpoint of the reconciliatory act of the Christ event (1: 10). The incorporation of the church into this event by its union in the Christ, causes it to proleptically share in that which is envisaged at the end (2: 1-10): the completion of the church's experience of the Christ-event.

The proleptic aspect of eschatology is also validated by the corollary of the Christ-event, namely the effusion of the Spirit as eschatological gift which is of a promissory nature (1: 11-14). The present first installment is commensurate to that which is to be bestowed at the end, in fullness. This proleptic aspect is underscored by the present experience of the church. That which the church experiences is not imaginary, but it is not complete, since, although the church has proleptically triumphed over evil forces, it still has to contend with the latter and their influences until the final end. 


\subsubsection{Eschatology in the process of realization}

God's purpose in bringing the times to completeness, emanates from the reconciliatory work of the Christ, which is to be realized in the present history of the church. This process of realization is evidenced by people coming to faith in Christ; or furthermore, as they are appropriated by God unto Himself, as His possession.

The evidence of this is validated by the many notions of the building and growth of the church, for example, the church reaching the totality of God's intended dimensions. This does not of necessity negate any terminus ad quem since the reaching of these dimensions are metaphorical of the spatial somatic comprehensions of the dimensions of Christ's love (Lemmer 1988: 304-324).

Inasmuch as completion presupposes the idea of realization, this oft-occurring notion, also supports the idea of eschatology in the process of realization. This process moves between the two eschatological focal points (realized and futuristic eschatology) and is also underscored by the present experience of the church, in that it is not completely free from evil onslaughts by inimical spiritual forces.

\subsubsection{Analeptic " eschatology}

The author of Ephesians clearly accepts the datum of a fixed point (spatially but also temporally in the future, or then from eternity, cf 1: 4, 20-23), from which the eschatological process is perspectivised. This is true inasmuch as the future reaches back into the present, in other words, that which is elsewhere indicated as intended future is portrayed as now real (2: 1-7). This is also true inasmuch the Spirit who is redolent from that which is future, is the harbinger of the future (and the otherworldly) into the present reality (cf 1: 13-14 and 1: 15-23). The analeptic aspect then also becomes evident in the life of the church by accepting that that which the believers may experience at times, comes to them by the Spirit from their future inheritance (2: 18, 5: 16-18ff). The future inheritance and all that it emanates from (the intentions and glory of God), provide a fixed point.

\subsubsection{Praesentic eschatology}

In itself this designation may indicate an entirely new and different facet of Ephesian eschatology, but this constitutes the converging area which results from the convergence of proleptic and analeptic eschatological facets. A praesentic dimension cannot be denied in Ephesians. However, it is not an autarchical dimension, but an inferred reality from the existence of the proleptic and the analeptic

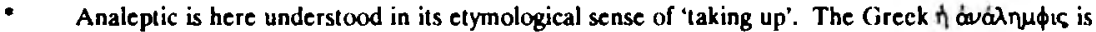
used for ascension (cf Bauer 1971: 114).
} 
eschatology. Furthermore, it is a depiction of expediency, since it is done with the readers' contingent situation in mind. This contingent situation obviously necessitated the actualization of the future (the analeptic aspects) in present terms, as well as the inevitable consequence of the proleptic elements in the Christ event. This praesentic eschatology is not only an objective fact; but an existential reality, when the Spirit temporarily impinges, at times, upon the earthly existence of the church.

\section{CONCLUSION}

\subsection{REPLY TO CERTAIN ISSUES}

By way of a summary, some of the issues raised in 2.2, may now be addressed. This interaction only responds to results and not to aspects of methodology or analysis.

\subsubsection{The relatedness of history and eschatology}

Rather than viewing history as either overtly sacred, evil or non-existent, the Ephesian author does not negate the existence of history as such. However, he merely concentrates on the salvation historical aspects of the establishing and the growth of the church by the proclamation of God's salvific designs. Any observation that general history is suspended or that it is innately evil in Ephesians, rests on syllogisms and cannot be substantiated. The present exalted existence of the Christian and the church in heaven can simply be explained from a possible contingent situation of the readers, rather than from presenting a universally axiomatic datum. This implies that a complete suspension of temporal categories is based on a fallacy. It can be thus deduced that futuristic expectations are intact, and it is unnecessary to follow a reductionist approach of explaining away any temporal notions as traditional rests. In this way Lindemann's 'existentialist' views on the situation of Ephesians is a denial of the clear future dimensions, in which the present situation of the church is not entirely that of the Christ, but merely 'according' ( $\kappa \propto \tau \alpha \dot{)})$ to that of the Christ in heaven. Lindemann's posit that in Ephesians the historical development is a development within space, is a denial of the proleptic notions which do not negate the temporal aspect, but rather underscores it. Similarly, his posit (Lindemann 1975: 193) of an already realized avake $\phi \alpha \lambda \alpha i \omega \sigma$ ls of everything, does not do justice to the pervading notion of developments and teleological perspectives in which time and space are at times correlational. 
One cannot agree with Lona's postulate that the traditional eschatological elements in Ephesians seem a correction of the strong praesentic view. In fact, in view of the possible communicative situation, it may be posited that these incidental references to a traditional eschatological view rather reflect a different situation: the author is communicating by association and is drawing from common stock. This implies that the actual traditional eschatological bases in both the minds of the readers and that of the author, were far wider than what is reflected in the discourse.

\subsubsection{Traditionsgeschichte' and Ephesians}

The former implies that any clear presentation of 'now-and-not yet' schemes and notions that reflect the Jewish apocalyptic ideas of the two-age doctrine, need not be explained away to make the letter accord with Gnostic thought constructs. Temporal and spatial categories exist together without any tension in the letter. Furthermore, eschatological perspectives offered in Ephesians would not be foreign to those in the so-called accepted Pauline letters.

\subsection{Ecclesiology in Ephesians}

Reading the letter in this way also has as corollaries that the church need not be viewed as the reference point of all history, neither does the church's present position replace all temporal categories, nor does it supplant Christ and the Spirit. Although the ecclesia, as the body and building of Christ, is undeniably accentuated in Ephesians, it does not imply that it has a one-sided existence in heaven. To postulate this is necessarily a negation of data that indicates clearly the existence of the ecclesia in the midst of the concrete sphere from which it was called, now however, on a different niveau and as a new and separate entity.

Rather than speaking of a 'heavenly ecclesiology' as such, the author of Ephesians is working out the implications of the church's incorporation in the Christ for their present situation. Although the church is important, it is never elevated to an autarchical entity such as the Spirit, but it is always and ever, dependent on the salvific acts of God, the Christ and the Spirit. Lona's (1984: 81) postulate that eschatology in Ephesians should be viewed from the point of view of the ecclesia has merit. Eschatology, however, remains the more comprehensive entity in Ephesians. Nevertheless, the author does perspectivise eschatology to address the contingent situation of Ephesians, which may, at times, imply a certain intrinsic 'subservience' of eschatology to ecclesiology. In this thesis it was found that the church operates on two levels: both in the evil world as well as in the heavenly sphere. However, from a temporal viewpoint, it is different from, but yet an integral part of this world. 
4.2 Final observation

If, as a presupposition, a more pertinent or nuanced eschatology is allowed to exist in Ephesians, and that eschatology represents the adaptation rather than aberration of traditional Pauline eschatology, it will be found that Ephesians does not present some kind of Fremdkörper, when compared with the rest of the corpus Paulinum.

\section{Works cited}

ADAI, J 1985. Der Heilige Geist als Gegenwart Gottes in den einzelnen Christen, in der Kirche und in der Welt: Studien zur Pneumatologie des Epheserbriefes. Frankfurt a M: Peter Lang.

BARTH, M 1974. Ephesians: A new translation with introduction and commentary. New York: Doubleday. (The Anchor Bible Vol 34 and 34A.)

BARTH, M 1984. Traditions in Ephesians. NTS 30, 3-25.

BAUER, W 1971. Griechisch-Deutsches Wörterbuch zu den Schriften des Neuen Testaments und der übrigen urchristlichen Literatur. Berlin: De Gruyter.

BEKER, JC 1980. Paul the apostle: The triumph of God in life and thought. Philadelphia: Fortress.

CARAGOUNIS, CC 1977. The Ephesian mysterion: Meaning and content. Uppsala University: Gleerup.

LEMMER, HR 1988. Pneumatology and eschatology in Ephesians - the role of the eschatological Spirit in the church. DTh thesis, University of South Africa.

LINCOLN, AT 1981. Paradise now and not yet: Studies in the role of the heavenly dimension in Paul's thought with special reference to his eschatology. Cambridge: Cambridge University Press.

LINDEMANN, A 1975. Die Aufhebung der Zeit: Geschichts-verständnis und Eschatologie im Epheserbrief. Gütersloh: Gerd Mohn.

LINDEMANN, A 1985. Der Epheserbrief. Zürich: Theologischer Verlag.

LONA, HE 1984. Die eschatologie im Kolosser- und Epheserbrief. Würzburg: Echter.

MUSSNER, F 1955. Christus das All und die Kirche: Studien zur Theologie des Epheserbriefes. Publisher unknown.

MUSSNER, F 1963. Die Geschichtstheologie des Epheser-briefes. AnBib 2, 59-64.

STEINMETZ, FJ 1969a. Protologisches Heils-Zuversicht: Die Strukturen des soteriologischen und christologischen Denkens im Kolosser- und Epheserbrief. Frankfurt a $\mathrm{M}$ : Knecht.

STEINMETZ, FJ 1969b. Parusie-Erwartung im Epheserbrief? Ein Vergleich. Bib $50 / 3,328-336$.

VAN ROON, A 1974. The authenticity of Ephesians. Leiden: Brill. 